\title{
LANGKAH-LANGKAH DAN TEKNIK EVALUASI HASIL BELAJAR PENDIDIKAN AGAMA ISLAM
}

\author{
Sawaluddin $^{1}$ dan Muhammad Siddiq ${ }^{2}$ \\ ${ }^{1}$ Sekolah Tinggi Agama Islam (STAI) Rokan Bagan Batu Rokan Hilir \\ ${ }^{2}$ Institut Agama Islam Abdullah Said Batam \\ Email: sawaluddinsiregar@stairokan.ac.id ${ }^{1}$; siddiqmuhammad79@gmail.com² $^{2}$
}

Website : https://jurnal.uin-antasari.ac.id/index.php/ptkpend/index

Received: 5 Juli 2020; Accepted: 7 Juli 2020; Published: 7 Juli 2020

\begin{abstract}
To know student learning outcomes in learning Islamic education, a teacher must have knowledge about evaluating learning outcomes, including the techniques and steps in evaluating learning outcomes, so that the evaluation conducted can be measured. This research was conducted to examine what are the steps and techniques of learning outcomes of religious education. The study is qualitative by analyzing several literature books and as the main data source. The results of the research are learning outcomes evaluation steps namely, compile an evaluation plan of learning outcomes, compile data, conduct data verification, process and analyze data, provide interpretation and draw conclusions, not further evaluation results. While learning outcomes evaluation techniques are test techniques, objective techniques and non test techniques.
\end{abstract}

Keywords: rare-steps; evaluation techniques; learning outcomes

\begin{abstract}
ABSTRAK
Untuk mengetahui hasil belajar siswa dalam pembelajaran pendidikan Agama Islam, seorang guru harus memiliki pengetahuan tentang evaluasi hasil belajar, diantaranya adalah teknik dan langkah-langkah evaluasi hasil belajar, sehingga evalusi yang dilakukan dapat terukur. Penelitian ini lakukan untuk mengkaji apa saja langkah-langkah dan teknik evaluasi hasil belajar Pendidikan Agama. Penelitian bersifat kualitatif dengan dengan menganalisi beberapa buku literatur dan sebagai sumber data utama. Adapun hasil penelitianya yaitu langkahlangkah evaluasi hasil belajar yaitu, menyusun rencana evaluasi hasil belajar, menghimpun data, melakukan verifikasi data, mengolah dan menganalisis data, memberikan interpretasi dan menarik kesimpulan, tidak lanjut hasil evaluasi. Sedangkan teknik evaluasi hasil belajar yaitu teknik tes, teknik objektif dan teknik non tes.
\end{abstract}

Kata Kunci: langkah-langkah; teknik evaluasi; hasil belajar

\section{PENDAHULUAN}

Seorang calon guru nantinya akan benar-benar dituntut profesional dalam menjalankan tugasnya sebagai seorang pendidik. Di dalam mengajar nantinya seorang guru dituntut untuk bisa memberikan pendidikan yang terbaik sehingga dapat mencapai tujuan pendidikan yang diinginkan (Sawaluddin Sawaluddin,at.al, 2018).

Evaluasi dalam pendidikan Islam cara atau teknik penilaian terhadap tingkah laku peserta didik berdasarkan standar perhitungan yang bersifat komprehensif dari seluruh aspek-aspek kehidupan mental psikologis dan spritual religius peserta didik (Sawaluddin Sawaluddin, at.al, 2018). Karena sosok pribadi yang diinginkan oleh pendidikan Islam bukan hanya pribadi yang bersifat religius, tetapi juga memilki ilmu dan berketerampilan yang sanggup beramal dan berbakti kepada Tuhan dan masyarakat (Laila Hamidah, at.al, 2019).

Dalam hal itu, evaluasi pendidikan adalah salah satu bagian dari kegiatan 
yang dilakukan oleh seorang guru untuk mendukung agar tercapainya tujuan pendidikan tersebut (Sawaluddin, 2017), dan diantara evaluasi yang dilakukan oleh guru yaitu evaluasi hasil belajar, dimana evaluasi ini dilakukan untuk mengukur sejauh mana pengetahuan dan keterampilan siswa setelah menerima materi dan arahan dari seorang guru. Evaluasi hasil belajar ini sangatlah penting dimana seorang guru harus benarbenar profesional dan objektif dalam melaksanakannya, karena disisi seorang guru akan memutuskan berhasil atau tidaknya seorang peserta didik (Sawaluddin, Sainab, 2019).

\section{METODE PENELITIAN}

Penelitian ini lakukan untuk mengkaji apa saja langkah-langkah dan teknik evaluasi hasil belajar pendidikan agama. Penelitian bersifat kualitatif dengan dengan menganalisi beberapa buku literatur dan sebagai sumber data utama.

\section{HASIL DAN PEMBAHASAN \\ Langkah-langkah Evaluasi Hasil Belajar}

Evaluasi merupakan bagian integral dari pendidikan atau pengajaran sehingga perencanaan atau penyusunan (Sawaluddin,at.al, 2020), pelaksanaan dan pendayagunaannya pun tidak dapat dipisahkan dari keseluruhan program pendidikan atau pengajaran (Slameto, 2001). Hasil dari evaluasi yang diperoleh selanjutnya dapat digunakan untuk memperbaiki cara belajar siswa (fungsi formatif).

Menurut Anas Sudiijono (2011), evaluasi dapat dilaksanakan tepat pada waktu yang diharapkan dan hasilnya tepat guna dan tepat arah, perlu mengikuti langkah-langkah berikut ini:

\section{Menyusun rencana evaluasi hasil belajar}

Perencanaan evaluasi hasil belajar itu umumnya mencakup: a. Merumuskan tujuan dilaksanakannya evaluasi. Hal ini disebabkan evaluasi tanpa tujuan maka akan berjalan tanpa arah dan mengakibatkan evaluasi menjadi kehilangan arti dan fungsinya.

b. Menetapkan aspek-aspek yang akan dievaluasi, misalnya aspek kognitif, afektif atau psikomotorik

c. Memilih dan menentukan teknik yang akan dipergunakan didalam pelaksanaan evaluasi misalnya apakah menggunakan teknik tes atau non tes

d. Menyusun alat-alat pengukur yang dipergunakan dalam pengukuran dan penilaian hasil belajar peserta didik, seperti butir-butir soal tes.

e. Menentukan tolok ukur, norma atau kriteria yang akan dijadikan pegangan atau patokan dalam memberikan interpretasi terhadap data hasil evaluasi.

f. Menentukan frekuensi dari kegiatan evaluasi hasil belajar itu sendiri (Sawaluddin, Sawaluddin., 2018).

\section{Menghimpun data}

Dalam evaluasi pembelajaran, wujud nyata dari kegiatan menghimpun data adalah melaksanakan pengukuran, misalnya dengan menyelenggarakan tes pembelajaran.

\section{Melakukan verifikasi data}

Verifiikasi data adalah proses penyaringan data sebelum dioleh lebih lanjut. Verifikasi bertujuan untuk memisahkan data yang dapat menjelaskan gambaran yang akan diperoleh mengenai peserta didik yang sedang dievaluasi dengna data yang tidak baik atau dapat mengaburkan gambaran yang akan diperoleh (Anas Sudiijono, 2011).

\section{Mengolah dan menganalisis data}

Mengolah dan menganalisis data bertujuan untuk memberikan makna terhadap data yang telah dihimpun dalam kegiatan evaluasi.ara mengolah dan menganalisi data dapat dilakukan dengan menggunakan teknik statistic, misalnya dengna menyusun dan mengatur data 
lewat tabel grafik atau diagaram, perhitungan rata-rata, standart deviasi, pengukuran korelasi, dsb.

\section{Memberikan interpretasi dan menarik kesimpulan}

Interpretasi merupakan verbalisasi makna yang terkandung dalam data yang telah mengalami pengolahan dan penganalisisan. Atas dasar interpretasi tersebut akan ditemukan kesimpulan yang mengacu kepada tujuan dilaksanakan evaluasi tersebut.

\section{Tidak lanjut hasil evaluasi}

Dari hasil evaluasi yang telah disusun, diatur, diolah, dianalisis dan disimpulkan sehingga diketahui maknanya, maka elevator dapat mengambil keputusan atau merumuskan kebijakan yang perlu sebagai tindak lanjut dari kegiatan evaluasi tersebut (Anas Sudiijono, 2011).

\section{Teknik Evaluasi Hasil Belajar}

Jika berbica tentang evaluasi pembelajaran, tidak terlepas dari teknik evaluasi itu sendiri. Ada dua macam teknik yang dapat digunakan dalam melaksanakan evaluasi, yaitu teknik tes dan teknik non tes. Teknik tes meliputi tes lisan, tes tertulis dan tes perbuatan. Tes lisan dilakukan dalam bentuk pertanyaan lisan di kelas yang dilakukan pada saat pembelajaran di kelas berlangsung atau di akhir pembelajaran. Tes tertulis adalah tes yang dilakukan tertulis, baik pertanyaan maupun jawabannya. Sedangkan tes perbuatan atau tes unjuk kerja adalah tes yang dilaksanakan dengan jawaban menggunakan perbuatan atau tindakan. Untuk lebih jelasanya dapat dilihat dibawah ini:

\section{Teknik Tes}

Tes adalah suatu teknik atau cara dalam rangka melaksanakan kegiatan evaluasi, yang didalamnya terdapat berbagai item atau serangkaian tugas yang harus dikerjakan atau dijawab oleh anak didik, kemudian pekerjaan dan jawaban itu menghasilkan nilai tentang perilaku anak didik tersebut. Jika ditinjau dari bentuk kegunaannya untuk mengukur siswa maka tes dibedakan menjadi 4 macam tes yaitu:

a. Tes Penempatan (placement test)

Pada umunya tes penempatan dibuat sebagai prates (pretest). Tujuan utamanya adalah untuk mengetahui apakah peserta didik telah memiliki keterampilanketerampilan yang diperlukan untuk mengikuti suatu program belajar dan sampai di mana peserta didik telah mencapai tujuan pembelajaran (kompetensi dasar) sebagaimana yang tercantum dalam Rencana Pelaksanaan Pembelajaran (RPP) mereka. Dalam hubungan dengan tujuan yang pertama masalahnya berkaitan dengan kesiapan siswa menghadapi program yang baru, sedangkan untuk yang kedua berkaitan dengan kesesuaian program pembelajaran dengan siswa (M. Chabib Thaha, 1990).

b. Tes Diagnostik

Tes Diagnostik adalah tes digunakan untuk mengetahui kelemahan-kelemahan siswa sehingga berdasarkan kelemahan tersebut dapat dilakukan pemberian perlakuan yang tepat. Artinya adalah tes yang digunakan untuk mengetahui kemampuan siswa sehinga dapat meletakkan siswa pada tempat yang sesuai dengan kemampuannya.

c. Tes Formatif

Tes formatif adalah tes yang dilakukan untuk memantau kemajuan belajar siswa selama proses belajar berlangsung, untuk memberikan balikan (feed back) bagi penyempurnaan program belajar-mengajar, serta untuk mengetahui kelemahan-kelemahan yang memerlukan perbaikan, sehingga hasil belajarmengajar menjadi lebih baik. Soal-soal tes formatif ada yang mudah dan ada pula yang sukar, bergantung kepada tugastugas belajar (learning tasks) dalam program pengajaran yang akan dinilai. Tujuan utama tes formatif adalah untuk memperbaiki proses belajar, bukan untuk menentukan tingkat kemampuan anak. Tes formatif sesungguhnya merupakan criterion-referenced test. Tes formatif 
yang diberikan pada akhir satuan pelajaran sesungguhnya bukan sebagai tes formatif lagi, sebab data-data yang diperoleh akhirnya digunakan untuk menentukan tingkat hasil belajar siswa. Tes tersebut lebih tepat disebut sebagai subtes sumatif. Jika dimaksudkan untuk perbaikan proses belajar, maka maksud itu baru terlaksana pada jangka panjang, yaitu pada saat penyusunan program tahun berikutnya.

\section{d. Tes Sumatif}

Tes sumatif diberikan saat satuan pengalaman belajar dianggap telah selesai. Tes sumatif diberikan dengan maksud untuk menetapkan apakah seorang siswa berhasil mencapai tujuan-tujuan instruksional yang telah ditetapkan atau tidak. Tujuan tes sumatif adalah untuk menentukan angka berdasarkan tingkatan hasil belajar siswa yang selanjutnya dipakai sebagai angka rapor. Ujian akhir dan ulangan umum pada akhir caturwulan atau semester termasuk ke dalam tes sumatif. Hasil tes sumatif jga dapat dimanfaatkan untuk perbaikan proses pembelajaran. Tes sumatif termasuk norm-referenced test. Cakupan materinya lebih luas dan soal-soalnya meliputi tingkat mudah, sedang, dan sulit. Setelah selesai menjelaskan tes ditinjau dari segi kegunaannya maka selanjutnya adalah menjelaskan bentuk-bentuk teknik tes tersebut.

\section{Tes objektif}

Tes objektif (objective test) menuntut peserta didik untuk memilih jawaban yang benar diantara kemungkinan jawaban yang telah disediakan, memberikan jawaban singkat, dan melengkapi pertanyaan atau pernyataan yang belum sempurna. Tes objektif sangat cocok untuk menilai kemampuan peserta didik yang menuntut proses mental yang tidak begitu tinggi seperti kemampuan mengingat kembali, kemampuan mengenal kembali, pengertian, dan kemampuan mengaplikasikan prinsip-prinsip. Tes objektif terdiri atas beberapa bentuk, yaitu benar-salah, pilihan ganda, menjodohkan, dan melengkapi atau jawaban singkat.

1) Bentuk Benar-Salah (true false) :

Contoh :

Petunjuk : Berilah tanda silang (X) pada huruf B jika jawabannya benar dan huruf $S$ bila jawabannya salah.

a) $\mathrm{B}-\mathrm{S}$ : Waqaf berarti menghentikan bacaan karena ada tanda waqaf.

b) $\mathrm{B}-\mathrm{S}$ : Yaumul hasyri artinya hari kebangkitan.

c) $\mathrm{B}-\mathrm{S}$ : Surat Al-Fatihah termasuk surat Makiyyah.

d) $\mathrm{B}-\mathrm{S}$ : Terbitnya matahari sebelah barat merupakan ciri besar hari kiamat.

Bentuk benar-salah yang lain adalah jawabannya telah disediakan, tetapi jawaban yang disediakan itu bukan $\mathrm{B}-\mathrm{S}$, melainkan Ya - Tidak. Contoh :

a) Ya - Tidak : Dajjal adalah seorang laki-laki dari kaum Yahudi.

b) Ya - Tidak : Dabbatul ardhi berarti keluarnya binatang bumi.

c) Ya - Tidak : Kematian manusia termasuk kiamat kubra.

d) Ya - Tidak : Rahasia hari kiamat dijelaskan dalam al-Qur'an surat alIkhlas.

Bentuk soal benar-salah dapat juga digunakan untuk mengukur kemampuan tentang sebab-akibat. Contoh (Ramayulis, 2008) :

a) B-S:Sholat rawatib dilaksana kan dua rakaat SEBAB sholat rawatib merupa kan sholat sunat.

b) B-S:Nabi sangat mencela orang yang lalai membayar hutang SEBAB hutang harus segera dilunasi.

c) B-S: Pada malam Idul Fitri umat Islam menguman dangkan kalimat takbir, tahlil dan tahmid SEBAB malam Idul Fitri adalah malam menjelang 1 Syawal.

d) B-S:Puasa wajib dimulai tanggal 1 Ramadhan SEBAB puasa diakhiri tanggal 1 Syawal.

e) B-S:Nikmat yang diberikan Allah wajib disyukuri SEBAB nikmat Allah tak sama untuk setiap orang. 


\section{2) Bentuk Pilihan Ganda (multiple choice)}

Soal tes bentuk pilihan-ganda dapat digunakan untuk mengukur hasil belajar yang lebih kompleks dan berkenaan dengan aspek ingatan, pengertian, aplikasi, analisis, sintesis dan evaluasi. Bentuk pilihan-ganda terdiri atas pembawa pokok persoalan dan pilihan jawaban. Pembawa pokok persoalan dapat dikemukakan dalam bentuk pertanyaan atau pernyataan (statement) yang belum sempurna yang sering disebut stem. Sedangkan pilihan jawaban itu mungkin berbentuk perkataan, bilangan atau kalimat dan sering disebut option.

Ada beberapa jenis bentuk pilihanganda ini, antara lain:

a) Distracters, yaitu option yang bukan merupakan jawaban yang benar.

Contoh :

Salah satu tanda besar menjelang hari kiamat adalah :

1. Semua urusan diserahkan kepada yang bukan ahlinya

2. Munculnya Dajjal.

3. Banyak terjadi pembunuhan dimanamana

4. Beratnya orang Islam untuk menjalankan syariat agamanya

5. Minuman keras sudah dianggap biasa

b) Analisis hubungan antar hal, yaitu untuk melihat kemampuan peserta didik dalam menganalisis hubungan antara pernyataan dengan alasan (sebab-akibat). Contoh :

Pada soal di bawah ini terdapat kalimat yang terdiri atas pernyataan (statement) dan alasan (reason).

Pilihan:

1. Jika pernyataan benar, alasan benar, dan alasan merupakan sebab dari pernyataan.

2. Jika pernyataan benar, alasan benar, tetapi alasan bukan merupakan sebab dari pernyataan.

3. Jika pernyataan benar, tetapi alasan salah.

4. Jika pernyataan salah, tetapi alasan benar.
5. Jika pernyataan salah, dan alasan salah. Soal:

Gubernur Jawa Barat tinggal di Bandung SEBAB Bandung merupakan ibu kota provinsi Jawa Barat.

Penjelasan:

1. "Gubernur Jawa Barat tinggal di Bandung" merupakan pernyataan yang benar.

2. "Bandung merupakan ibu kota Provinsi Jawa Barat" merupakan alasan yang benar dan merupakan sebab dari pernyataan.

Jawaban : Jadi, jawaban yang betul adalah A.

c) Variasi negatif, yaitu setiap pertanyaan atau pernyataan mempunyai beberapa kemungkinan jawaban dan disediakan satu kemungkinan jawaban yang salah. Tugas siswa adalah memilih jawaban yang salah tersebut. Contoh :

Teladan yang bisa diambil dari kisah Nabi Musa a.s adalah, kecuali :

1. Menolong tanpa pamrih

2. Konsekwen terhadap janji

3. Berani menegakkan kebenaran

4. Sikap ragu-ragu.

d) Variasi berganda, yaitu memilih dari beberapa kemungkinan jawaban yang semuanya betul, tetapi ada satu jawaban yang paling betul. Tugas siswa adalah memilih jawaban yang paling betul itu. Contoh :

Para siswa hendaknya menghormati ...

1. Sesama teman

2. Guru-gurunya

3. Orang tuanya

4. Teman, guru, dan orang tuanya

e) Variasi yang tidak lengkap, yaitu pertanyaan atau pernyataan yang memiliki beberapa kemungkinan jawaban yang belum lengkap. Tugas siswa adalah mencari satu kemungkinan jawaban yang tepat dan melengkapinya. Contoh :

Surat Al-Fatiha disebut juga sab'ul matsani. Artinya ...

1. 5 ayat yang dibaca .....

2. 6 ayat yang dibaca .....

3. 7 ayat yang dibaca ..... 


\section{8 ayat yang dibaca .....}

\section{3) Bentuk Menjodohkan (matching)}

Soal tes bentuk menjodohkan sebenarnya masih merupakan pilihan ganda. Perbedaannya adalah pilihan ganda terdiri atas stem dan option, kemudian testi tinggal memilih salah satu option yang diberikan. Sedangkan bentuk menjodohkan terdiri atas kumpulan soal dan kumpulan jawaban yang keduanya disusun pada dua kolom yang berbeda. Kolom sebelah kiri menunjukkan kumpulan soal dan kolom sebelah kanan menunjukkan kumpulan jawaban. Jumlah alternatif jawaban harus dibuat lebih banyak dari jumlah soal. Contoh 1 :

Petunjuk : Di bawah ini terdapat dua daftar, yaitu daftar A dan daftar B. Tiaptiap kata yang terdapat pada daftar A mempunyai pasangannya masing-masing pada daftar B. Anda harus mencari pasangan-pasangan itu. Tulislah nomor kata yang anda pilih itu di depan pasangannya masing-masing.

\section{4) Bentuk Jawaban Singkat (short answer) dan Melengkapi (completion)}

Kedua bentuk tes ini masingmasing menghendaki jawaban dengan kalimat dan atau angka-angka yang hanya dapat dinilai benar atau salah. Soal bentuk jawaban singkat biasanya dikemukakan dalam bentuk pertanyaan. Contoh :
a) Siapakah malaikat yang menanyai di alam kubur?
b) Apa nama agamamu ?
c) Siapa nama Tuhan-mu ?
d) Apa nama kitab sucimu ?
e) Apa nama kiblatmu ?

Sedangkan soal bentuk melengkapi (completion) dikemukakan dalam kalimat yang tidak lengkap. Contoh :
a) Alam barzakh disebut juga alam
b) Nabi Musa a.s lahir pada zaman raja ......... di negeri
c) Hadis adalah .... Rasulullah, sedangkan sunnah adalah ..... Rasulullah.

d) Neraka jahannam diperuntukkan bagi
orang-orang ............
e) Hukum akikah adalah sunah

Cara mengoreksi bentuk tes objektif :

Sesudah item disusun, kemudian diadakan tes, maka selanjutnya kita mengoreksi jawaban siswa dari tiap item yang diberikan. Untuk mengoreksi jawaban tersebut kita harus menggunakan kunci jawaban (scoring key) sebagai acuan dan patokan yang pokok. Jika kunci jawaban ini sudah disediakan, maka siapapun dapat mengoreksi jawaban tersebut secara cepat dan tepat.

a. Tes Lisan (oral test), yaitu suatu bentuk tes yang menuntut jawaban siswa dalam bentuk bahasa lisan. Peserta didik akan mengucapkan jawaban dengan kata-katanya sendiri sesuai dengan pertanyaan ataupun perintah yang diberikan.

b. Tes Perbuatan (performance test), yaitu bentuk tes yang menuntut jawaban siswa dalam bentuk perilaku, tindakan, atau perbuatan. Peserta didik bertindak sesuai dengan apa yang diperintahkan dan ditanyakan. Misalnya, coba praktikkan bagaimana cara melaksanakan sholat yang baik dan benar.

\section{Teknik Non Tes}

Para ahli berpendapat bahwa dalam mengadakan evaluasi terhadap hasil belajar, kita harus menggunakan teknik tes dan nontes, sebab hasil-hasil pelajaran bersifat aneka ragam. Hasil pelajaran dapat berupa pengetahuan teoritis, keterampilan dan sikap. Pengetahuan teoritis dapat diukur dengan menggunakan teknik tes. Keterampilan dapat diukur dengan menggunakan tes perbuatan. Adapun perubahan sikap dan petumbuhan peserta didik dalam psikologi hanya dapat diukur dengan teknik nontes, misalnya observasi, wawancara, skala sika p, angket, check list, dan rating scale.

Anas Sudijono (2011) membagi teknik evaluasi non-tes ini hanya kepada 4 
macam saja, yaitu: pengamatan (observation/al-ta'ammul = التأمل $)$, wawancara (interview/al-hiwar = الحوار), angket (questionnaire/Istifta = إستفناء), dan pemeriksaan dokumen (documentary analysis). Sedangkan Zainal Arifin (2011) membagi teknik evaluasi non-tes kepada 10 macam, yaitu; observasi (observation), wawancara (interview), skala sikap (attitude scale), daftar cek (check list), skala penilaian (rating scale) (Anas Sudijono 2011), angket (questioner), studi kasus (case study), catatan insidental (anecdotal records), sosiometri, inventori kepribadian.

Namun perbedaan tersebut sesungguhnya terletak pada perbedaan penggunaan istilah dan kebahasaan saja, bukan pada substansi. Karena apa yang diuraikan oleh Zainal Arifin secara terurai dan terinci ditemukan juga dalam pembahasan empat bentuk pembahasan teknik evaluasi non-tes yang dikemukakanoleh Anas Sudijono. Oleh karenanya, di sini penulis hanya ingin membatasi evaluasi non-tes ini hanya kepada beberapa bentuk yang sering digunakan dalam mengevaluasi hasil pembelajaran. Berikut adalah beberapa teknik evaluasi non-tes;

\section{a. Observasi}

Menurut Zainal Arifin (2011), observasi adalah suatu proses pengamatan dan pencatatan secara sistematis, logis, objektif, dan rasional mengenai berbagai fenomena, baik dalam situasi yang sebenarnya maupun dalam situasi buatan untuk mencapai tujuan tertentu. Pendapat tersebut sejalan dengan pendapat Anas Sudijono (2011) yang mendefinisikan observasi dengan pengamatan dan pencatatan secara sistematis terhadap fenomena-fenomena yang sedang dijadikan sasaran pengamatan.

Dalam evaluasi pembelajaran, observasi dapat digunakan untuk menilai proses dan hasil belajar peserta didik, seperti tingkah laku peserta didik pada waktu guru Pendidikan Agama Islam menyampaikan pelajaran di kelas, tingkah laku peserta didik pada jam-jam istirahat atau pada saat terjadinya kekosongan pelajaran, pada saat berdiskusi, mengerjakan tugas dan lain-lain. Selain itu juga dapat digunakan untuk menilai penampilan guru dalam mengajar, suasana kelas, hubungan sosial sesama, hubungan sosial sesama peserta didik, hubungan guru dengan peserta didik, dan perilaku sosial lainnya.

Berikut adalah langkah-langkah penyusunan pedoman observasi sekaligus contoh Pedoman observasi praktik mengajar;

a) Merumuskan tujuan observasi

b) Membuat lay-out atau kisi-kisi observasi

c) Menyusun pedoman observasi

d) Menyusun aspek-aspek yang akan diobservasi, baik yang berkenaan dengan proses belajar peserta didik dan kepribadiannya maupun penampilan guru dalam pembelajaran.

e) Melakukan uji coba pedoman observasi untuk melihat kelemahan-kelemahan pedoman observasi.

f) Merevisi pedoman observasi berdasarkan hasil uji coba.

g) Melaksanakan observasi pada saat kegiatan berlangsung.

h) Mengolah dan menafsirkan hasil observasi.

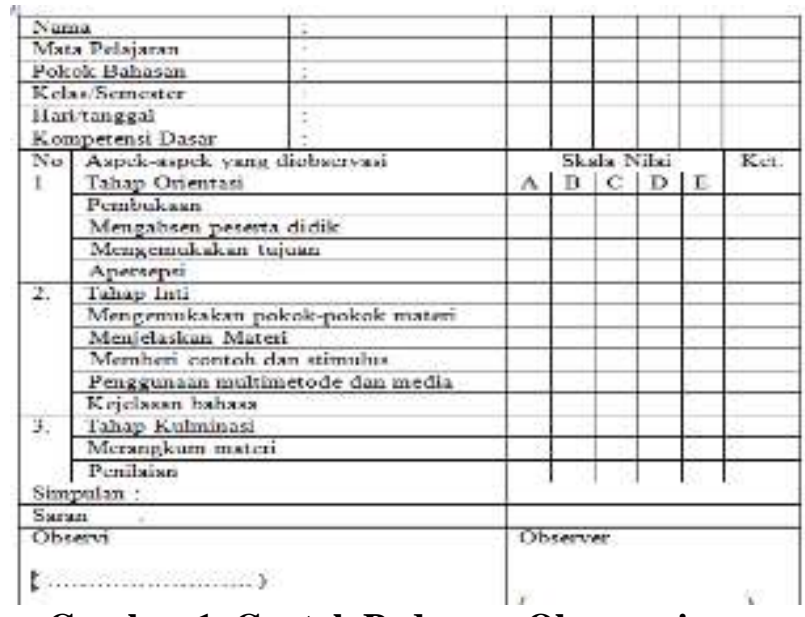

Gambar 1. Contoh Pedoman Observasi Praktik Mengajar 
Contoh 2. Observasi penilaian keterampilan peserta didik

Mata Pelajaran: Keterampilan

Topik : Membuat Kaligrafi dari kertas.

Kelas

Nama Siswa

Hari \& Tanggal :

Jam Pelajaran

Tabel 1. Observasi Penilaian Keterampilan Peserta Didik

\begin{tabular}{|c|l|c|l|}
\hline No & Kegiatan/aspek yang dinilai & Skor/Nilai & Keterangan \\
\hline 1. & Persiapan alat-alat (bahan) & $\ldots \ldots \ldots \ldots \ldots$ & \\
\hline 2. & Kombinasi bahan & $\ldots \ldots \ldots \ldots \ldots$ & \\
\hline 3. & Kombinasi warna & $\ldots \ldots \ldots \ldots \ldots$ & \\
\hline 4. & Cara mengerjakan & $\ldots \ldots \ldots \ldots \ldots$ & \\
\hline 5. & Ketepatan waktu mengerjakan & $\ldots \ldots \ldots \ldots \ldots$ & \\
\hline 6. & Hasil pekerjaan & $\ldots \ldots \ldots \ldots \ldots$ & \\
\hline
\end{tabular}

Hasil penilaian dengan menggunakan instrument tersebut di atas bersifat individual. Setelah selesai, nilainilai individual itu dimasukkan ke dalam daftar nilai yang bersifat kolektif, seperti contoh berikut ini:

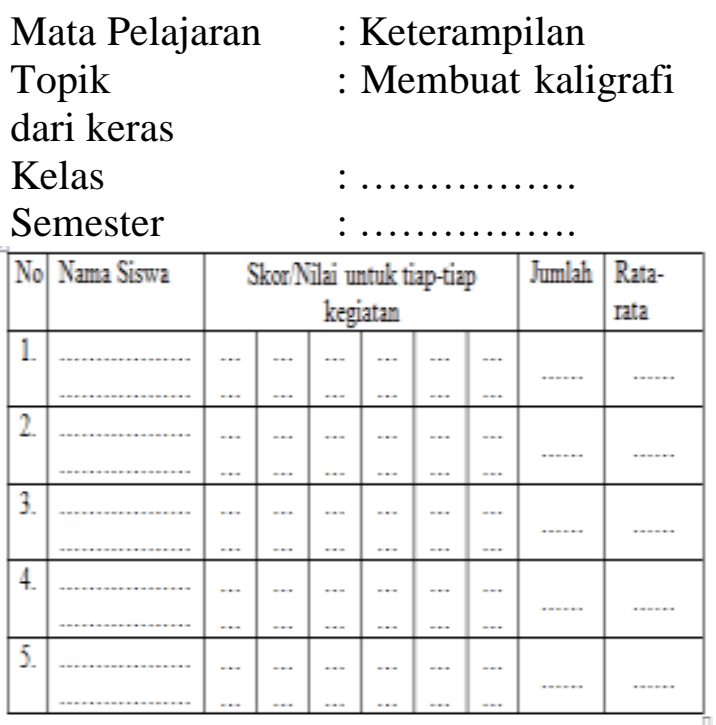

Gambar 2. Contoh Daftar Nilai Siswa

\section{b. Wawancara}

Menurut Zainal Arifin (2011), wawancara merupakan salah satu bentuk alat evaluasi jenis non-tes yang dilakukan melalui percakapan dan tanya jawab, baik langsung maupun tidak langsung dengan peserta didik. Wawancara langsung adalah wawancara yang dilakukan secara langsung antara pewawancara dengan orang yang diwawancarai tanpa melalui perantara. Sedangkan wawancara tidak langsung adalah wawancara yang dilakukan melalui perantaraan orang lain ataupun media. Berbeda dengan Zainal Arifin, Anas Sudijono (2011) membagi wawancara kepada wawancara terpimpin (guided interview) yang dikenal juga dengan wawancara berstruktur/sistematis dan wawancara tidak terpimpin (un-guided interview) yang sering dikenal juga dengan wawancara bebas atau wawancara tidak sistematis.

Kegiatan wawancara ini bertujuan untuk memperoleh informasi secara langsung guna menjelaskan suatu hal atau situasi dan kondisi tertentu. Disamping itu juga bertujuan untuk melengkapi suatu penyelidikan ilmiah dan untuk memperoleh data agar dapat memengaruhi situasi atau orang tertentu.

Untuk menyusun pedoman wawancara, dapat mengikuti langkahlangkah sebagai berikut;

a) Merumuskan tujuan

b) Membuat kisi-kisi atau lay out dan pedoman wawancara

c) Menyusun pertanyaan sesuai dengan data yang diperlukan dan bentuk pertanyaan yang diinginkan. Untuk itu perlu diperhatikan kata-kata yang digunakan, cara bertanya dan jangan 
membuat peserta didik bersikap defensife.

d) Melaksanakan uji coba untuk melihat kelemahan-kelemahan pertanyaan yang disusun, sehingga dapat diperbaiki lagi.

e) Melaksanakan wawancara dalam situasi sebenarnya.

Contoh;

\section{Tabel 2. Kisi-Kisi Pedoman Wawancara}

\begin{tabular}{|l|l|l|l|l|}
\hline No & Masalah & Tujuan & Pertanyaan & $\begin{array}{l}\text { Bentuk } \\
\text { pertanyaan }\end{array}$ \\
\hline & & & & \\
\hline
\end{tabular}

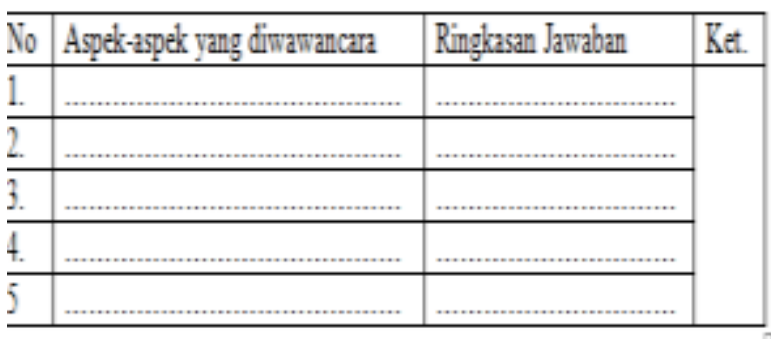

Gambar 3. Format Pedoman Wawancara

\section{c. Skala Sikap (Attitude Scale)}

Sikap merupakan suatu

kecenderungan tingkah laku untuk berbuat sesuatu dengan cara, metode, teknik, dan pola tertentu terhadap dunia sekitarnya, baik berupa orang-orang maupun berupa objek-objek tertentu. Sikap mengacu kepada perbuatan atau perilaku seseorang, tetapi tidak berarti semua perbuatan identik dengan sikap. Perbuatan seseorang mungkin saja bertentangan dengan sikapnya.

Dalam mengukur sikap, guru hendaknya memperhatikan aspek kognisi, afeksi dan juga konasi. Disamping itu, guru juga harus memilih salah satu model skala sikap, seperti dengan menggunakan bilangan, frekuensi, kode bilangan atau huruf, istilah-istilah yang bersifat kualitatif ataupun yang menunjukkan status/kedudukan.

Salah satu model untuk mengukur sikap, yaitu dengan menggunakan skala sikap yang dikembangkan oleh Likert.
Dalam skala Likert, peserta didik tidak disuruh memilih pernyataan-pernyataan yang positif saja, tetapi memilih juga pernyataan-pernyataan yang negatif. Tiap item dibagi ke dalam lima skala, yaitu: sangat setuju, setuju, tidak tahu, tidak setuju, dan sangat tidak setuju. Setiap pernyataan positif diberi bobot $4,3,2,1$, 0 , sedangkan pernyataan negative diberi bobot sebaliknya, yaitu $0,1,2,3$, dan 4 .

Untuk menyusun skala Likert, dapat mengikuti langkah-langkah sebagai berikut:

a) Memilih variabel afektif yang akan diukur

b) Membuat beberapa pernyataan tentang variabel afektif yang akan diukur.

c) Mengklasifikasikan pernyataan positif dan negative

d) Menentukan jumlah gradual dan frase atau angka yang dapat menjadi alternative pilihan.

e) Menyusun pernyataan dan pilihan jawaban menjadi sebuah alat penilaian.

f) Melakukan uji coba

g) Membuang butir-butir pernyataan yang kurang baik.

h) Melaksanakan penilaian.

Contoh sikap peserta didik terhadap mata pelajaran bahasa Indonesia

\begin{tabular}{|c|c|c|c|c|c|c|}
\hline No & Penratan & 5S & $\mathrm{S}$ & TI & TS & STS \\
\hline $0 !$ & $\begin{array}{l}\text { Saya memperiagkan dir motuk } \\
\text { meneims pelajarm Bahss } \\
\text { Indenesia dikelss. }\end{array}$ & & & & & \\
\hline 02 & $\begin{array}{l}\text { Saya berperan aktif dalam kegiatan } \\
\text { pentedajeren Bahasa Indunesie. }\end{array}$ & & & & & \\
\hline 03 & $\begin{array}{l}\text { Saya ska menggunak:an Bahasa } \\
\text { Lodenesia yeug baik dam benar. }\end{array}$ & & & & & \\
\hline 04 & $\begin{array}{l}\text { Saya teriaik dengan artikd yang } \\
\text { berimbezan dangan badaya } \\
\text { Indenesia. }\end{array}$ & & & & & \\
\hline 05 & $\begin{array}{l}\text { Saya menopekava materi dari sasu } \\
\text { bahasa Indonesia dan membaca } \\
\text { brikn-buks sumber setagai } \\
\text { penunjaza. }\end{array}$ & & & & & \\
\hline 06 & 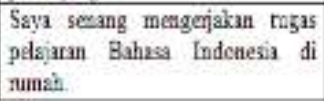 & & & & & \\
\hline 07 & Dst. & & & & & \\
\hline
\end{tabular}

Gambar 4. Contoh Sikap Peserta Didik

a. Daftar Cek (Check List).

Daftar cek adalah suatu daftar yang berisi subjek dan aspek-aspek yang 
akan diamati. Daftar cek dapat memungkinkan guru sebagai penilai mencatat tiap-tiap kejadian yang betapapun kecilnya, tetapi dianggap penting. Ada bermacam-macam aspek perbuatan yang biasanya dicantumkan dalam daftar cek, kemudian tinggal memberikan tanda centang ( $\checkmark$ ) pada tiap-tiap aspek tersebut sesuai dengan hasil penilaiannya.

Contoh 1:

Daftar cek tentang keaktifan peserta didik dalam diskusi kelompok pada mata pelajaran PAI

\begin{tabular}{|c|c|c|c|}
\hline $\mathrm{B}_{0}$ & Newa sisma & \begin{tabular}{|llll}
$S B$ & $B$ & $C$ \\
\end{tabular} & $\mathbb{K}$ \\
\hline 01 & Newo Piaroso & & \\
\hline 02 & Elin Roclin & & \\
\hline 03 & Ace Af̧cadi & & \\
\hline OH & Angsiz Zalindra & & \\
\hline 05 & Ardil Variana & & \\
\hline
\end{tabular}

Contoh 2:

Daftar cek tentang kebiasaan belajar.

Nama

Kelas

Umur

Sekolah

\begin{tabular}{|c|c|c|c|c|c|c|}
\hline $\mathrm{N}_{0}$ & $\begin{array}{l}\quad \text { Tanggal Obsemsi } \\
\text { Aspex- } \\
\text { sspek yung dinilai }\end{array}$ & 19 & 29 & 39 & 49 & Dst. \\
\hline 01 & Kegiatan diskosi & & & & & \\
\hline$\overline{Q 2}$ & Menbuat rarghuman & & & & & \\
\hline 61 & Latihan & & & & & \\
\hline 04 & Belyar sendín & & & & & \\
\hline 05 & Belajar kelempok & & & & & \\
\hline
\end{tabular}

\section{b. Angket}

Angket termasuk alat untuk mengumpulkan dan mencatat data atau informasi, pendapat, dan paham dalam hubungan kausal. Angket mempunyai kesamaan dengan wawancara, kecuali dalam implementasinya. Angket dilaksanakan secara tertulis, sedangkan wawancara dilaksanakan secara lisan. Angket terdiri atas beberapa bentuk, yaitu: a) Bentuk angket berstruktur, yaitu angket yang menyediakan beberapa kemungkinan jawaban. Bentuk angket berstruktur terdiri atas tiga bentuk, yaitu: b) Bentuk jawaban tertutup, yaitu angket yang setiap pertanyaannya sudah tersedia berbagai alternatf jawaban.

c) Bentuk jawaban tertutup, tetapi pada alternatif jawaban terakhir diberikan secara terbuka. Hal ini dimaksudkan untuk memberikan kesempatan kepada peserta didik untuk menjawab secara bebas.

d) Bentuk jawaban bergambar, yaitu angket yang memberikan jawaban dalam bentuk gambar.

e) Bentuk angket tak berstruktur, yaitu bentuk angket yang memberikan jawaban secara terbuka. Peserta didik secara bebas menjawab pertanyaan tersebut. Hal ini dapat memberikan pemahaman yang lebih mendalam tentang situasi, tetapi kurang dapat dinilai secara objektif. Jawabannya tidak dapat dianalisis secara statistik sehingga kesimpulannyapun hanya merupakan pandangan yang bersifat umum.

Ada beberapa hal yang harus diperhatikan dalam menyusun dan menyebarkan angket, yaitu:

a. Setiap pertanyaan harus menggunakan bahasa yang baik dan benar, jelas, singkat, tepat, dan sederhana sehingga mudah dimengerti oleh peserta didik, seperti;

1. Hindari pertanyaan yang ambigu

2. Hindari kata tambahan, seperti "biasanya", dan "seringkali".

b. Jangan membuat pertanyaan yang mengarahkan pada jawaban. Misalnya, "kamu tidak menganggap dia anak yang cerdas, bukan?"

c. Jangan menggunakan dua kata sangkal dalam satu kalimat pertanyaan. Misalnya: "apakah kamu tidak senang untuk tidak membaca buku pelajaran?"

d. Hindari pertanyaan berlaras dua, seperti: "apakah kamu senang belajar membaca dan berhitung?"

e. Buatlah pertanyaan yang tepat sasaran. Misalnya, "apakah kamu suka belajar computer di rumah?" pertanyaan ini tidak tepat. Bagaimana jika anak tersebut tidak mempunyai 
computer? Untuk itu, perlu dibuat dua pertanyaan, seperti (1) apakah kamu mempunyai computer di rumah? (2) Jika Ya, apakah kamu senang belajar computer di rumah?

f. Jika terdapat angket yang tidak diisi, maka harus membagikan lagi angket itu kepada peserta didik yang lain sebanyak yang tidak menjawab (tidak mengembalikan).

g. Dalam menyebarkan angket, hendaknya dilampirkan surat pengantar angket.

h. Hendaknya jawaban tidak terlalu banyak dan tidak terlalau sedikit.

Contoh kuesioner/angket bentuk pilihan ganda untuk mengungkap hasil belajar ranah afektif (kurikulum dan GBPP Mata Pelajaran Pendidikan Agama Islam Tahun 1994).

1. Terhadap teman-teman sekelas saya yang rajin dan khusu' dalam menjalankan ibadah shalat, saya:

a. Merasa tidak harus meniru mereka

b. Merasa belum pernah memikirkan untuk shalat dengan rajin dan khusu'

c. Merasa ingin seperti mereka

d. Sedang berusaha agar saya rajin dan khusu'

e. Merasa iri hati dan ingin seperti mereka.

\section{PENUTUP}

Adapun hasil penelitianya yaitu langkah-langkah evaluasi hasil belajar yaitu, menyusun rencana evaluasi hasil belajar, menghimpun data, melakukan verifikasi data, mengolah dan menganalisis data, memberikan interpretasi dan menarik kesimpulan, tidak lanjut hasil evaluasi. Sedangkan teknik evaluasi hasil belajar yaitu teknik tes, teknik objektif dan teknik non tes.

\section{DAFTAR PUSTAKA}

Anas Sudiijono, Pengantar Evaluasi Pendidikan, cetakan ke-11 Jakarta; PT. Raja Grafindo Persada, 2011

Laila Hamidah, Sawaluddin Siregar, Nuraini Nuraini, Kepribadian Guru
Pendidikan Agama Islam Menurut Buya Hamka, Tarbiyah: Jurnal Ilmiah Kependidikan e-ISSN: 25488376 Vol. 8 No. 2 Juli - Desember $2019(135-146)$

M. Chabib Thaha, Tehnik-tehnik Evaluasi Pendidikan (Jakarta: PT Raja Grafindo, 1990), hlm. 35

Ramayulis, Ilmu Pendidikan Islam, (Jakarta:Kalam Mulia, 2008), cet. ke 10, hlm. 229

Sawaluddin Sawaluddin, Koy Sahbuddin Harahap, Muhammad Syaifuddin, Sainab Sainab, Syahrul Akmal Latif, Development of the Potential Senses, Reason, and Heart According to the Qur'an and its Application in Learning, Advances in Social Science, Education and Humanities Research, volume 253, 3rd Asian Education Symposium (AES 2018), pp.508-511

Sawaluddin Sawaluddin, Munzir Hitami, Zikri Darussamin, Sainab Sainab, The Potential of the Senses in AlQuran as the Basic Elements of the Human Physic and Its Application in Learning, Advances in Social Science, Education and Humanities Research, volume 261, International Conference on Islamic Education (ICIE 2018), pp. 158-162.

Sawaluddin, Koy Sahbudin Harahap, Supardi Ritonga, Muhammad Ramli, Prosedur Pengembangan Evaluasi Pembelajaran Pendidikan Agama Islam, Jurnal Pendidikan Islam Vol. 8 No.3 Januari - Juni 2020, pp.79-94

Sawaluddin, Potensi Indra, Akal, dan Kalbu Menurut Al-Qur'an dan Aplikasinya Dalam Pengembangan Pendidikan Dasar, Pekanbaru: UIN Suska Riau, Disertasi, 2017, pp. 402-404

Sawaluddin, Sainab, The Intelligent Meaning In The Qur'an: Nalysis Of The Sure Potential In The Al-Qur'an As A Dimension Of Human Psychic Insaniah, Jurnal Madania: Volume 9 
: 2, 2019 (e-ISSN 2620-8210 | pISSN pp. 373-395

Sawaluddin, Sawaluddin. "Konsep Evaluasi Dalam Pembelajaran Pendidikan Islam." Jurnal Pendidikan Agama Islam AlThariqah 3, No. 1 (July 13, 2018): 39. Doi:10.25299/ Althariqah. 2018.Vol3 (1).39-53

Slameto, Evaluasi Pendidikan, (Jakarta: Bumi Aksara, 2001), hlm. 54

Zainal Arifin, Evaluasi Pembelajaran (Prinsip, Teknik, Prosedur), Cetakan ketiga (Bandung; PT. Remaja Rosdakarya, 2011), hlm. 153-177 